\title{
Resoluçōes da Conferência Nacional da classe trabalhadora
}

\author{
21, 22 e 23 de agosto de 1981 \\ Praia Grande (SP) - Colônia de Férias dos \\ Sindicatos dos Trabalhadores Têxteis
}

\section{DIREITO DO TRABALHO}

\section{Declaração de princípios}

A legislação trabalhista no Brasil não exprime os interesses da classe trabalhadora, e pelo seu caráter antidemocrático distorce e contraria os sonhos e conquistas do povo, mantendo e aprofundando a situação de insegurança e miséria que marginaliza milhões de trabaIhadores, entravando sua organização.

Os trabalhadores brasileiros exigem um Código Nacional do Trabalho elaborado através de amplas discussões pelos trabalhadores e seus sindicatos, como um passo fundamental para o estabelecimento de uma efetiva democracia.

A classe trabalhadora brasileira, no entanto, está convencida de que as soluções de seus problemas não dependem somente do Poder Judiciário, ou simplesmente de uma coleção de leis. A solução das questões que interessam aos trabalhadores depende fundamentalmente da queda do regime militar antinacional, antipopular, antidemocrático e da conquista das mais amplas liberdades democráticas.

A solução das questões que interessam aos trabalhadores depende de seu nível de mobilização e organização, implementada por um sindicalismo combativo, autêntico e construído pela base. 


\section{REIVINDICAÇÕES E PLATAFORMAS DE LUTA E MOBILIZAÇÃO}

\section{Constituição}

- Elaboração de uma Constituição que garanta os direitos fundamentais da classe trabalhadora; o trabalho produtivo é socialmente útil para todos; a prática efetiva dos direitos civis e políticos e das liberdades democráticas sem nenhuma discriminação; a plena liberdade sindical, inclusive o direito de greve amplo e irrestrito.

\section{Código Nacional de Trabalho}

- Que seja formado um grupo de trabalho, composto por representantes do movimento sindical e com o assessoramento da OAB e da Associação Nacional de Advogados Trabalhistas, para elaborar, em prazo curto, um projeto de Código Nacional de Trabalho. Este grupo de trabalho deve se valer do acúmulo de discussões já existente no movimento sindical sobre o assunto e elaborar um Código simples, que seja compreendido, discutido e assumido por todos os trabalhadores brasileiros e seja uma alternativa às investidas, golpes e pacotes do governo e dos patrões.

Enquanto não existir o CNT, lutar:

- pela revogação imediata do Título $V$ da CLT;

- pelo pleno cumprimento dos dispositivos da Consolidação das Leis do Trabalho (CLT) de proteção aos trabalhadores e demais leis trabalhistas;

- pela revogação dos dispositivos da Constituição e de todas as leis e regulamentos limitativos dos direitos econômicos e sociais dos trabalhadores e da ação sindical.

\section{Direito ao trabalho}

- reconhecimento e garantia de que toda relação de trabalho gera um vínculo empregatício, gerando direitos e acessos aos benefícios sociais, assim como o direito à sindicalização;

- eliminação da locação de mão-de-obra; 
- que seja garantido ao trabalhador o direito ao trabalho, independentemente de acusações que possam existir contra ele em órgão de segurança;

- direito ao trabalho para todos os deficientes físicos, através das seguintes medidas:

1. incentivar e garantir empregos com todas as garantias trabalhistas;

2. garantir o retorno ao emprego quando este novamente necessitar de tratamento;

3. direito ao tratamento para todos os trabalhadores acidentados no trabalho, sob orientação de profissionais especializados, através do INPS, em centros de reabilitação profissional em todo o território nacional;

4. garantir o retorno à função anterior ou o retorno em nova função, respeitando-se a resolução de capacidade profissional dada pelas equipes nos centros de reabilitação.

\section{Estabilidade no emprego}

- estabilidade no emprego a todos os trabalhadores a partir da contratação e extinção dos contratos de experiência e os empregos temporários;

- a automação e mudanças tecnológicas não constituem causas para dispensa.

\section{Seguro-desemprego}

- enquanto o Estado brasileiro não garantir o direito ao trabalho;

- instituição do seguro-desemprego cobrindo o pagamento salarial até que o trabalhador tenha outro emprego;

- o seguro-desemprego será devido após 30 dias do desligamento do emprego;

- criar um fundo-desemprego gerido e administrado pelos sindicatos, ouvida a assembléia-geral da categoria;

- as empresas e o Estado contribuirão paritariamente com o valor de $2 \%$ calculado sobre o faturamento das empresas, sem permissão do repasse aos preços de venda. 


\section{Fundo de Garantia por Tempo de Serviço (FGTS)}

- coexistência do FGTS com a estabilidade, garantida sempre no pedido de demissão, aposentadoria ou falecimento, a equivalência entre a indenização e os depósitos fundiários;

- o FGTS constitui, independentemente de opção, um fundo financeiro a ser gerido pelos trabalhadores;

- a utilização dos depósitos do FGTS como pecúlio ou pensão para atendimento das necessidades dos trabalhadores mediante autorização dos sindicatos;

- em caso de rescisão admitida de contrato, o empregador deverá indenizar o trabalhador com o valor de depósito acrescido da devida correção monetária;

- repúdio às tentativas de extensão do FGTS aos trabalhadores rurais;

- possibilidade de levantamento imediato do FGTS pelo trabalhador em caso de pedido de dispensa;

- elevação do depósito do FGTS de $8 \%$ para um doze avos da remuneração mensal recebida pelo empregado.

\section{Direito de greve}

- legislação assegurando o princípio constitucional do amplo e irrestrito direito de greve, inclusive na administração pública;

- abolição de todas as leis restritivas ao direito de greve.

\section{Convenção Coletiva de Trabalho}

- os trabalhadores e seus sindicatos têm o direito de negociar os salários e todas outras condições de trabalho e de vida através de convenções coletivas profissionais ou interprofissionais com qualquer empregado; inclusive na administração pública e igualmente no âmbito nacional;

- $\quad$ nas empresas, os sindicatos podem negociar contratos a fim de completar, adaptar e melhorar as convenções coletivas nacionais; 
- o atual contrato individual de trabalho, aguardando sua extinção, deve conter dispositivos mínimos legais elaborados com a participação dos sindicatos, entre os quais a unificação das reivindicações e das datas-base.

\section{Salário mínimo real unificado}

- fixação do salário mínimo real unificado cobrindo as necessidades em alimentação, saúde, educação, lazer, habitação, transporte e vestuário, do trabalhador e de sua família;

- extensão do SMRU aos trabalhadores assalariados rurais;

- participação do DIEESE na elaboração dos cálculos dos reajustes salariais, inclusive do SMRU, assegurando a manutenção do poder definitivo das rendas do trabalho (salário real garantido).

\section{Salário profissional}

- instituição do salário profissional conforme as condições específicas de conhecimentos técnicos necessários nas diversas atividades;

- a garantia do salário profissional aos funcionários públicos de acordo com a sua profissionalização.

\section{Fiscalização do trabalho - higiene e segurança do trabalho}

- eliminação dos agentes insalubres;

- proibição do uso de defensivos agrícolas à base de mercúrio;

- participação do DIESAT (que deve ter amplitude nacional) na definição dos critérios de insalubridade e periculosidade nas diversas atividades;

- participação dos sindicatos e delegados sindicais na fiscalização, inclusive na constatação pericial ou técnica;

- criar equipes conjuntas de fiscalização, com participação dos sindicatos;

- obrigatoriedade de as empresas aceitarem atestados assinados por qualquer médico;

- garantir pessoal mais qualificado e em maior número na fiscalização; 
- aumentar as multas derivadas dos autos de infração lavrados contra as empresas;

- CIPAs formadas exclusivamente por representantes dos trabalhadores eleitos por voto direto e secreto em assembléias coordenadas pelo sindicato, sem interferência da empresa.

\section{Jornada de Trabalho}

Assegurar uma remuneração digna do trabalho com:

- redução da jornada de trabalho para 40 horas semanais sem redução do salário, respeitadas as jornadas já conquistadas, inferiores a 40 horas;

- eliminação das horas extras e pagamento com adicional de $100 \%$ enquanto aquelas não forem extintas.

\section{Direitos da mulher trabalhadora}

- eliminação de todo e qualquer princípio que crie discriminações entre o homem e a mulher, garantindo a ela uma real equiparação salarial, quando no mesmo trabalho;

- direito de a gestante mudar de função, quando a exercida for prejudicial à gestação;

- proibição da exigência de exame de gravidez quando da admissão de mulheres;

- ampliação da licença-maternidade para seis meses;

- obrigatoriedade da construção e manutenção de creches nas empresas e bairros, mantidas pelas próprias empresas e pelo poder públi$\mathrm{co}$, sob controle efetivo dos trabalhadores através de seus sindicatos;

- lutar pela mudança da lei, para que a exigência de creches se refira ao número de trabalhadores, sem diferença de sexo, e não de mulheres na empresa;

- as crianças devem ficar nas creches até a idade escolar, estando vinculada a sua saída da creche à matrícula em escola pública;

- comemorar no dia 12 de outubro o "dia de defesa do filho do trabalhador"; 
- direito de acesso da mulher aos cursos profissionalizantes;

- abolição das discriminações em relação à mulher quando das promoções nas empresas;

- extensão de fato dos direitos trabalhistas às mulheres que realizam trabalho a domicílio,

- aposentadoria da mulher aos 25 anos de trabalho;

\section{Trabalho do menor}

- proibição do trabalho ao menor de 16 anos, garantindo-lhe, sempre o ensino gratuito e a formação técnico-profissional;

- garantia do salário mínimo ao maior de 16 anos, mesmo quando aprendiz, garantindo-se o piso salarial de sua categoria;

- sem prejuízo da remuneração, ao menor será garantida a jornada de seis horas de trabalho por dia;

- ao trabalhador menor não será permitido o trabalho por revezamento, de turnos, devendo, sempre, ter horário fixo de trabalho, sendo proibido o trabalho noturno;

- ao trabalhador menor não será permitida a transferência da localidade onde foi contratado;

- serão nulas as quitações dadas por menor sem assistência de seu responsável e do sindicato;

- ao menor estudante será assegurado o direito de se ausentar dos serviços em dias de prova e exames escolares, sem prejuízo salarial;

- o aprendizado efetivado junto às empresas deverá ser sempre fiscalizado pelo sindicato, nos termos do contrato coletivo;

- efetivação do trabalhador menor em suas funções, após a prestação de serviço militar.

\section{Direitos dos trabalhadores domésticos}

Não discriminação quanto aos direitos econômicos, sociais e culturais dos trabalhadores domésticos, pela concessão entre outros, das garantias seguintes:

- jornada de oito horas de trabalho; 
- salário mínimo;

$-13^{\circ}$ salário;

- aviso prévio;

- FGTS;

- descanso semanal remunerado;

- salário-família;

- auxílio-natalidade;

- seguro contra acidente de trabalho;

- direito às negociações sobre férias;

- reconhecimento jurídico da categoria de empregado doméstico.

\section{Justiça do Trabalho}

- devolver e garantir as prerrogativas da Justiça do Trabalho para a solução dos conflitos que não possam ser solucionados pelas convenções coletivas de trabalho. Para isso:

- celeridade processual: aumento do número de juntas de conciliação e julgamento e extensão da jurisdição das atuais; aumento do número de tribunais regionais do trabalho e aumento das turmas nos TRTs já existentes, aumentos de turmas no Tribunal Superior do Trabalho;

- competência: conhecer e julgar litígios relativos à natureza de acidente do trabalho nos casos de julgamento das questões que envolvem empregados regidos pela CLT e estatutário e que são servidores públicos;

- depósito recursal: obrigatoriedade, por parte do empregador, do depósito do total da condenação, tanto para interposição de recurso ordinário quanto para a interposição de agravo de petição;

- supressão do valor de alçada para recurso;

- nas audiências de instrução, as empresas deverão contestar cinco dias antes e depositar verbas salariais, $13^{\circ}$ salário e FGTS, suprimindo-se as audiências iniciais;

- participação do trabalhador ou seu representante na execução de perícias determinadas pela Justiça do Trabalho; 
- falência: medida cautelar obrigatória determinando arresto dos bens patrimoniais como garantia dos direitos trabalhistas, para todos os efeitos e sempre são créditos privilegiados os direitos trabalhistas, oficiando-se imediatamente o juízo falimentar.

- processo trabalhista: criar um Código de Processo do Trabalho com a participação dos sindicatos na sua elaboração;

- representação classista: democratização da escolha dos representantes dos trabalhadores nas representações classistas, sob efetivo controle das entidades sindicais. Os representantes dos trabalhadores devem ser eleitos pelo voto direto e secreto de suas categorias;

- eliminação da prescrição, para que o trabalhador possa reclamar, a qualquer momento, seus direitos.

\section{SINDICALISMO}

As entidades sindicais são o efetivo instrumento de luta dos trabaIhadores brasileiros, que têm o sindicato como a sua referência para a defesa dos seus interesses, apesar da legislação que restringe a liberdade e a autonomia sindical. É dentro dos sindicatos, portanto, por onde devem passar as lutas dos trabalhadores.

A mobilização e a organização dos trabalhadores nos seus locais de trabalho são condições indispensáveis para o fortalecimento do sindicato e de sua própria democracia interna. O que une os trabalhadores em torno de seus sindicatos são as suas contradições de classe com o patronato, sua luta comum contra a exploração e por melhores condições de vida, independentemente de suas convicções religiosas, políticas ou ideológicas. A representação de uma categoria numa mesma base territorial por um único sindicato - reivindicação histórica da classe trabalhadora - é, portanto, o seu melhor instrumento de luta.

A fim de assegurar o caráter unitário da entidade sindical, deve imperar em seu interior a mais ampla democracia, com profundo respeito às decisões das assembléias. A militância sindical deve ser estimulada, sem qualquer tipo de restrição ou preconceito. 
O sindicato, para que atinja as suas finalidades e possa constituir-se em um instrumento de representação autêntica dos trabalhadores, deve ser livre e autônomo, não só em relação ao Estado, como também em relação aos partidos políticos e credos religiosos. Embora não tenha caráter partidário, o sindicato é uma entidade eminentemente política, cabendo-Ihe desenvolver a luta pela emancipação política, social e econômica, bem como a solidariedade dos trabalhadores. Os sindicatos não podem dissociar a luta pela melhoria das condições de vida dos trabalhadores da luta geral do povo brasileiro, pela democracia e pelo progresso social.

Não cabe ao Estado qualquer ingerência nas atividades sindicais, razão pela qual repudiamos o seu poder de intervir, cassar mandatos e até mesmo de fechar entidades. Exigimos, portanto, a revogação de toda a legislação restritiva à autonomia sindical.

Nós, os trabalhadores, devemos nos organizar numa Central Única dos Trabalhadores, a partir das bases de nossas entidades sindicais, com amplitude bastante para representar, sem exceção, todos os trabalhadores, da cidade e do campo.

\section{Unidade sindical}

Os sindicatos têm o direito de exercer suas atividades em representação dos trabalhadores segundo seus Estatutos, livremente adotados sem controle dos poderes públicos ou dos empregadores.

Os sindicatos serão organizados em correspondência ao ramo de atividade econômica e à mesma base territorial, decidindo a Assembléia dos trabalhadores qualquer dúvida quanto à representação da categoria, garantida a unidade sindical.

\section{Liberdade e autonomia sindical}

Os sindicatos devem ser independentes do Estado, do patronato, das confissões religiosas, dos partidos e outras associações políticas.

Todos os trabalhadores têm o direito de se expressar, democraticamente nos fóruns de deliberação dos seus sindicatos, independentemente de suas convicções, acatando-se a decisão da maioria. 
Os sindicatos devem definir e traçar seus programas e sua ação sem nenhuma ingerência externa.

Liberdade de sindicalização: os trabalhadores têm o direito, inclusive na administração pública, de ingressar no sindicato de sua categoria e participar em toda atividade sindical sem autorização nem controle da autoridade pública ou dos empregadores.

Estatutos: os membros do sindicato determinam livremente os Estatutos e regulamentos, a organização, o funcionamento e as atividades de seu sindicato.

Eleição: os trabalhadores, membros de sindicatos, ativos, aposentados ou desempregados têm o direito de eleger seus dirigentes e de serem eleitos para os diferentes cargos, em conformidade com os Estatutos da organização.

Eleição, programas e gestão: os sindicatos têm o direito de fixar livremente os sistemas de eleição de seus dirigentes e órgãos executivos, bem como de organizar sua gestão interna e formular seus programas de ação.

Central Única dos Trabalhadores (CUT): os sindicatos têm o direito de reunir-se interprofissionalmente em Central Única.

Filiação internacional: os sindicatos, respeitada a vontade da Assembléia, têm o direito de filiar-se a organizações sindicais internacionais de sua escolha.

\section{Organização sindical de base $\mathbf{O}$ sindicato na empresa}

Direito de reunião: os trabalhadores têm o direito de reunir-se em cada local de trabalho, de recolher cotizações, ler e difundir a imprensa sindical de sua predileção, realizar todo tipo de propaganda sindical e exercer plenamente seus direitos civis e políticos.

Delegados sindicais: os trabalhadores têm o direito de eleger nas empresas públicas ou privadas, bem como em qualquer local de trabalho, delegados sindicais, delegados de empresa ou dirigentes das organizações sindicais de base. Podem igualmente ser eleitos para as mesmas funções.

Comissão de empresa: os trabalhadores, através de seus sindicatos, têm o direito de constituir comissões de empresa visando à plena 
atividade sindical no local de trabalho, na defesa dos interesses dos trabalhadores e no reforço da unidade da classe trabalhadora.

O Estatuto das comissões de empresa deve ser aprovado em assembléia dos sindicalizados da empresa.

Garantia dos delegados sindicais e das comissões de empresa: As comissões de empresa e os delegados sindicais serão garantidos pela convenção coletiva, em participar com as condições mínimas de funcionamento seguintes:

1.Estabilidade no emprego e garantia contra a demissão durante o período de sua candidatura, o exercício de seu mandato e um período, a ser fixado de comum acordo, depois do mandato;

2.livre acesso dos delegados sindicais e representantes das comissões de empresa aos locais de trabalho, instalações e estabelecimentos da empresa. Este acesso é extensivo aos locais de alojamento, no caso em que os empregados alojem os trabalhadores;

3.determinado número de horas, tomadas dentro do tempo de trabaIho, para cumprir com eficiência suas funções;

4.direito das comissões de empresas de dispor de locais de reunião e quadros de anúncios, postos à disposição pela empresa.

CIPA: a criação de CIPA livremente eleita pelos trabalhadores com a participação dos sindicatos.

Relações internacionais: Os sindicatos têm o direito de receber informação, de ser consultados sobre os aspectos econômicos e sociais derivados de acordos internacionais do governo da União.

Os sindicatos têm o direito de participar das diferentes estruturas de discussão, negociação e decisão sobre as questões econômicas, sociais e culturais internacionais que afetam as condições de vida e trabalho dos trabalhadores.

\section{Manutenção financeira dos sindicatos}

Cotização e fundos sindicais: os sindicatos têm o direito de, inclusive nos locais de trabalho, recolher as cotizações sindicais na forma 
definida pelos Estatutos e de aprovar, receber e dar solidariedade e ajuda mútua em nível nacional;

Os sindicatos administram os fundos sindicais sem qualquer controle das autoridades públicas e dos empregadores;

Os fundos sindicais e os bens adquiridos pelos sindicatos não podem ser bloqueados em nenhum caso e constituem patrimônio inviolável dos trabalhadores.

O patrimônio e fundos sindicais são indivisíveis.

\section{Contribuição sindical}

1.O movimento sindical deve ter como meta a sua auto-sustentação, intensificando as diversas maneiras de obter recursos próprios entre os trabalhadores.

2.Os trabalhadores devem discutir amplamente as formas de suas atuais contribuições financeiras para as entidades sindicais, tendo sempre como objetivo, torná-las livres e atuantes.

3.Enquanto existir a contribuição sindical, sendo ela dinheiro do trabalhador, deve ser destinada unicamente em seu benefício. Assim, reivindicamos que $20 \%$ (vinte por cento) da contribuição sindical destinados ao Ministério do Trabalho revertam em favor da categoria.

4.Enquanto existir a contribuição sindical, que se reivindique a revogação da atual legislação e sua aplicação, atribuindo-se às assembléias dos sindicatos competência para decidir acerca de utilização desse recurso financeiro.

\section{O enquadramento sindical}

A atual estrutura sindical embora mantenha em tese o princípio da unidade sindical, propicia, em alguns casos, a divisão dos trabalhadores.

A Comissão de Enquadramento Sindical é um órgão que administra a divisão dos trabalhadores, tanto em nível corporativo como geográfico.

O resultado desta política de divisão é que os trabalhadores são separados em sindicatos diferentes, com distintas diretorias, Assembléias e Campanhas, com flagrante prejuízo para força de seu movimento. O que une os trabalhadores são os interesses frente ao mesmo 
patrão, que, em geral, é representado por um único sindicato e não os seus ofícios, hoje divididos em sindicatos diferentes.

Não é à toa que os sindicatos mais fortes hoje em dia são, exatamente, aqueles que representam trabalhadores de grandes ramos de atividade econômica. Não é por acaso também o desejo dos patrões de dividir os metalúrgicos em vários sindicatos.

Reconhecemos que este tipo de divisão levada a efeito pelo atual enquadramento sindical deve ser combatido e que a discussão sobre o tipo de sindicato que mais convém aos trabalhadores deve imediatamente iniciar-se da maneira mais ampla e democrática, respeitando-se as especificidades de certas categorias.

\section{Comissão Pró-CUT}

Que esta primeira Conclat seja considerada um passo fundamental e irreversível da luta pela construção da CUT. Nesse sentido, deve ser eleita nesta plenária da Conclat uma Comissão Nacional Pró-CUT com as atribuições de:

a)coordenar a execução das resoluções da Conclat e, particularmente, a da realização em agosto de 1982 do Congresso Nacional das Classes Trabalhadoras;

b)prestar apoio e solidariedade às lutas de todos os trabalhadores e às lutas específicas das diversas categorias profissionais.

Foi eleita pelo plenário da Conclat a Comissão Nacional Pró-CUT, composta por 56 (cinqüenta e seis) sindicalistas, sendo 24 (vinte e quatro) rurais e 32 (trinta e dois) urbanos.

\section{SAÚDE E PREVIDÊNCIA SOCIAL}

\section{Declaração de princípios}

A atual estrutura de saúde do país é antidemocrática e antipopular. Propostas positivas nessa área só serão alcançadas quando os trabaIhadores conquistarem seus legítimos direitos e tiverem voz ativa nas 
decisões políticas. Em outras palavras, não há nem haverá saúde fora de uma democracia autêntica.

Nos últimos 17 anos de regime militar, a situação da classe trabaIhadora sofreu grande piora, com reflexos diretos nas suas condições de saúde. Foram rebaixados os salários, reprimidos os trabalhadores e seus sindicatos, abolidas conquistas duramente obtidas. No campo da saúde, podemos citar a restrição dos direitos dos trabalhadores acidentados, a criação dos convênios (que tanta distorção tem trazido à assistência médica), a piora das condições gerais de vida da população, além de estatísticas falsas que encobrem os números de mortes e acidentes de trabalho etc. Acreditamos que a realidade tem mostrado fartamente a essência antioperária e antipopular do modelo econômico e político atual.

Agora mesmo o governo tenta penalizar os trabalhadores brasileiros pela péssima gestão dos fundos da Previdência Social, anunciando a intenção de aumentar o percentual da contribuição devida pelo trabaIhador ao INPS, e de extinguir a aposentadoria por tempo de serviço. Os trabalhadores aproveitam a oportunidade para afirmar perante a Nação que rechaçam ambas as medidas, ao mesmo tempo em que responsabilizam os governos autoritários que se sucederam nos últimos anos pela escabrosa situação do setor.

Os trabalhadores, nesta $1^{\text {a }}$ Conclat, denunciam ainda a precariedade da assistência médica, a insuficiência das medidas de saúde pública e saneamento, a ausência de condições mínimas para a preservação da saúde do povo brasileiro e a falta de requisitos básicos para o trabalho dos profissionais de saúde. Essa política de saúde elitista e privatizante privilegia as grandes empresas médicas privadas, a indústria multinacional de medicamentos e equipamentos, em detrimento do trabalhador.

Por outro lado, a Previdência Social transformou-se antes em instrumento de manipulação de interesses contrários ao trabalhador do que a favor deste. Seus recursos financeiros, provenientes fundamentalmente da contribuição compulsória dos assalariados, são alocados para grupos empresariais lucrativos a serviço do patronato. Além dis- 
so, as verbas dos orçamentos da União, dos Estados e dos Municípios destinados ao setor são irrisórias.

A luta pela democratização da saúde é também meta prioritária dos trabalhadores. E essa democratização só será estabelecida na medida em que se instaurar e aprofundar a democratização da sociedade brasileira, com a participação do povo no debate e na busca de soluções para as questões de saúde e da previdência.

Os delegados da $1^{\text {a }}$ Conclat, reafirmando o direito de cada trabalhador à condição de proteção médica e sanitárias modernas e democráticas, dão ênfase a que se faça medicina preventiva e prevenções de acidentes e moléstias profissionais e destacam como Reivindicações Prioritárias:

\section{Benefícios da Previdência}

\section{Previdência Social urbana e rural}

\section{Reajustes dos proventos previdenciários}

Os proventos das aposentadorias e pensões ao longo dos anos vêm sendo reajustados de forma diferente da dos trabalhadores em atividade, e em valores sempre inferiores à variação do custo de vida.

Para corrigir estas distorções reivindica-se:

a) que os proventos das aposentadorias e pensões, sem discriminação, sejam reajustados imediatamente, de forma a repor integralmente os poderes aquisitivos que possuíam na época de sua concessão;

b) para os ajustes a serem concedidos de ora em diante, sejam adotados os mesmo critérios vigentes na legislação da política salarial para os trabalhadores da ativa, fundados nos seguintes princípios:

I. O enquadramento nas faixas da legislação salarial será feito levando-se em conta o salário mínimo em vigor na data da aplicação do reajuste. E não no salário mínimo anterior como vem sendo feito pela Previdência Social;

II. Aplicação da taxa de produtividade nacional (PIB) apurado no exercício anterior aos reajustamentos dos proventos:

c) que fique estabelecido o maior salário mínimo do país como o menor provento de aposentadoria e pensões 


\section{Salário de benefício}

Que o salário de benefício, para todos os casos de prestação continuada, seja calculado com base nos últimos 12 salários de contribuição do segurado, corrigidos monetariamente. Os salários dos últimos 12 meses, todavia, não poderão ser computados nos valores decorrentes de promoção, devidamente comprovada, em relação aos salários percebidos no período de vinte e quatro meses anteriores.

\section{Limite de salário de contribuição}

Seja elevado o limite de contribuição previdenciária para 30 salários mínimos.

\section{Valor de referência}

Seja eliminada a figura do valor de referência para qualquer efeito de direito ou obrigação previdenciária.

\section{Auxílio-funeral}

Seja assegurada extensão do auxílio-funeral pela morte da esposa ou companheira, dos filhos menores de 18 anos e das filhas menores de 21 anos. Que o benefício tenha valor igual a três salários mínimos regionais.

\section{Auxílio-natalidade}

Que o auxílio-natalidade seja igual a três salários mínimos.

\section{Aposentadoria da mulher}

Que a aposentadoria da mulher seja concedida aos 25 anos de trabalho, em valor integral, e que aos 20 anos de trabalho seja concedido em valor equivalente a $80 \%$ do salário-benefício. Que seja assegurado, também, o abono-permanência, aos 25 anos, na data-base de 20 a $25 \%$, respectivamente, do salário de benefício.

\section{Salário-família}

Que o salário-família seja estendido à esposa ou companheira e aos filhos, de sexo masculino até 21anos de idade e feminino até 24 , na hipótese de serem estudantes ou não terem rendimentos próprios.

Que o valor do salário-família seja correspondente a $20 \%$ do salário mínimo regional vigente. 


\section{Abono anual}

Que o abono anual seja pago ao trabalhador afastado para gozo de auxílio-doença ou qualquer outro benefício, na proporção de um doze avos da última remuneração percebida, corrigida monetariamente, para cada mês de afastamento.

\section{Carência}

Seja eliminada a exigência de cumprimento de prazo de carência para a concessão de auxílio-doença, aposentadoria por invalidez e auxílio-natalidade.

Seja eliminada, também, a exigência de cumprimento de novo prazo de carência àqueles que perderam a qualidade de segurado, mas tenham pago cinco anos de contribuição previdenciária, para efeito de concessão de aposentadoria por tempo de serviço e por idade.

\section{Pensão}

O valor da pensão paga aos dependentes do segurado falecido será sempre igual aos proventos de aposentadoria percebida ou que teria direito de perceber na data do falecimento.

\section{Aposentadoria especial}

Seja eliminada a necessidade de formulários para a comprovação de exercício de atividade enquadrada na legislação de aposentadoria especial, desde que o exercício da função da atividade esteja devidamente registrado na Carteira Profissional.

Que qualquer empresa onde exista a presença de agentes agressivos, perigosos ou insalubres, seja obrigada a manter registrados no Ministério da Previdência Social competentes laudos técnicos em que descreva minuciosamente as condições de trabalho, a fim de facilitar a concessão da aposentadoria especial.

Que seja concedida a aposentadoria especial aos 25 anos de trabalho aos segurados integrantes da categoria dos desenhistas profissionais.

Que seja revogado o dispositivo legal que estabelece o limite de idade para aposentadoria especial dos eletricitários, desde que trabaIhem com tensão igual ou superior a 220 volts. 


\section{Aposentadoria por tempo de serviço}

Que seja revigorado o antigo sistema de cálculo do valor da aposentadoria por tempo de serviço, passando este a representar o valor integral do salário de benefício, ou seja, $100 \%$ desse valor, porquanto hoje é de $95 \%$.

\section{Previdência social rural}

1. Que nenhum benefício de Previdência Social Rural seja inferior ao valor do maior salário mínimo vigente no Brasil.

\section{Aposentadoria por velhice}

a)Alteração da legislação em vigor, a fim de conceder aos trabalhadores rurais a aposentadoria por velhice aos 55 anos de idade, quando homem, e aos 50 anos quando mulher.

b)Que a aposentadoria por velhice seja concedida à mulher ou companheira do trabalhador rural, bastando comprovação da atividade rural, mesmo que em atividade de conjunto familiar.

\section{Aposentadoria por invalidez}

a)Que a incapacidade para o trabalho seja verificada em relação a qualquer atividade, como no sistema vigente;

b)Que seja estendida referida aposentadoria por invalidez à mulher ou companheira do trabalhador rural.

\section{Aposentadoria por tempo de serviço}

a)Seja criada a aposentadoria por tempo de serviço com a exigência de 35 anos de serviço, para o homem, e 25 anos para a mulher;

b)Não seja fixado nenhum limite de idade para a concessão do benefício.

\section{Pensão por morte}

Seja estendido este benefício à viúva do trabalhador rural, quando for o caso, aos filhos daquele que tenha falecido anteriormente à vigência da Lei Complementar n.11.

\section{Auxílio-funeral}

Que este auxílio seja devido por morte de qualquer membro da família e não só por morte do trabalhador rural e sua mulher. 


\section{Auxílio-doença e demais benefícios}

Criação de benefício de auxílio-doença ao trabalhador rural, bem como extensão de benefícios concedidos aos trabalhadores urbanos tais como: auxílio-natalidade, salário-maternidade; salário-família e auxílio-reclusão.

\section{Legislação acidentária e acidentes do trabalho}

\section{I.Garantia de emprego ao acidentado}

1. Ao trabalhador afastado da atividade, em decorrência de acidente do trabalho, moléstia profissional ou doença do trabalho, seja garantida a estabilidade no emprego, quando do seu retorno à empresa, pelo período necessário à sua reabilitação e/ou readaptação profissional.

2.Que o movimento sindical procure, por todos os meios, ampliar a introdução de cláusulas, nas convenções coletivas de trabalho, de garantia de estabilidade no emprego, ao acidentado.

3.Que o movimento sindical envide esforços no sentido de que sejam criadas juntas médicas compostas de médicos do INAMPS, das empresas e dos sindicatos com o objetivo de conferir a lisura das altas médicas que importem na suspensão de benefícios.

\section{II.Comissão interna de prevenção de acidentes - CIPA}

1.Que seja intensificada a pressão sindical no sentido de que a NR-5 da Portaria 3.214/78 seja alterada, conferindo à CIPA, poderes para atuar diretamente na proteção dos ambientes de trabalho.

2.Que a estabilidade do cipeiro seja idêntica à do dirigente sindical, ressalvadas as características particulares quanto ao mandato do referido cipeiro, inclusive aos suplentes.

3.Que seja obrigatória (previsto em Lei) a participação e orientação do sindicato na eleição dos cipeiros, devendo o sindicato ser comunicado, com pelo menos 30 dias de antecedência da data das eleições.

4.Que todos os cipeiros representantes dos trabalhadores sejam sindicalizados.

5.Que seja obrigatória a liberdade total para a Campanha Eleitoral dos candidatos a representar os trabalhadores na CIPA. 
6.Que o presidente da CIPA seja eleito pelos próprios cipeiros e não indicados pela empresa.

7.Que seja encaminhado ao sindicato correspondente cópia das atas da CIPA.

\section{III.Acidentes de trabalho rural}

1.Que o valor mínimo do auxílio-doença acidentário seja igual ao maior salário mínimo do país.

2.Que o art. 9o do Decreto n. $76.022 / 75$ seja alterado para evitar que a capacidade total e definitiva seja aferida de modo absoluto e passe a ser considerada em relação às atividades próprias do trabalho e não em relação "a qualquer atividade".

3.Que a legislação passe a considerar acidente do trabalho rural todo aquele verificado no trajeto de ida e volta para o trabalho, em relação à residência do trabalhador rural.

4.Que a legislação passe a considerar acidente de trabalho, também, todo aquele ocorrido no trajeto de ida e volta para o local de comercialização dos produtos plantados e colhidos pelo trabalhador rural.

5.Que a legislação equipare o trabalhador rural ao trabalhador urbano em matéria de acidente de trabalho, passando a ampará-lo com todos os benefícios da Lei n. 6.367 de 1976, tais como:

a)A majoração de $25 \%$ na aposentaria por invalidez, quando o aposentado necessitar da assistência permanente de outra pessoa;

b)Auxílio-acidente de 40\%, mensal, vitalício em caso de incapacidade parcial que importe na necessidade de mudança para outra atividade;

c)Auxílio suplementar de $20 \%$ do maior salário mínimo do país pago mensal e vitaliciamente a partir do término do auxílio-doença, quando houver lesão ou redução funcional que implique maior esforço para o exercício de atividade habitual.

d)Pecúlio-invalidez no valor de 15 vezes o maior salário mínimo do país;

e)Pecúlio por morte no valor de 30 vezes o maior salário mínimo do país; 
f)Que a aposentadoria por acidente do trabalho do trabalhador rural, seja paga de acordo com o salário de convenção ou dissídio coletivo da categoria.

6.Que o prazo de oito dias para comunicação do acidente seja abolido e que sejam revogadas as normas internas da Previdência, por estarem em desacordo com a legislação vigente.

7.Que os médicos de hospitais e sindicatos que mantêm convênios com a Previdência Social, sejam oficialmente credenciados para emitir laudos médicos por acidentes do trabalho rural.

\section{Garantias ao aposentado}

1.Que seja alterado o Art. 9o do Decreto n. 79.037/76, no sentido de reconhecer ao Segurado em gozo de aposentadoria especial, por velhice ou por tempo de serviço, que volta a exercer atividade, os mesmos direitos daqueles que estão na ativa, no caso de ocorrência de acidade de trabalho, ou seja:

I.Auxílio-doença acidentária;

II.Pensão por morte;

III.Auxílio-acidente;

IV.Aposentadoria por invalidez;

V.Pecúlio por invalidez;

VI.Abono anual;

VII.Pecúlio por morte;

VIII.Assistência médica;

IX.Reabilitação profissional.

2.Que o movimento sindical desenvolva intensa luta para que o trabalhador, ao se aposentar, tenha um benefício que lhe propicie condição digna de vida para si e para sua família, de modo a não ser obrigado a retornar à atividade para sobreviver.

\section{Legislação}

Que seja entregue ao trabalhador acidentado, cópia da "CAT" (Comunicação de Acidente de Trabalho) e da "FAA" (Ficha de Análise de Acidente). 
Restauração do Decreto-Lei n. 7.036/44, naquilo que beneficia o trabalhador, notadamente no que diz respeito às tabelas acidentárias, graus de incapacidade, comunicação obrigatória do acidente pela empresa, sob comunicação de multa revertida em favor do acidentado e não do segurador.

Sejam revistos os cálculos das aposentadorias por invalidez acidentária, no sentido de que não haja prejuízo para o acidentado, cumprindo-se a determinação legal de que o salário deste seja o mesmo do percebido se estivesse na ativa.

Obrigatoriedade da comunicação do acidente ou moléstia profissional, ou doença do trabalho sofrida pelo trabalhador ao órgão de classe, sob pena de multa em favor da Entidade Sindical, visando ao controle dos acidentes, estudo preventivo e sugestões para evitá-los, bem como, a defesa dos direitos do acidentado.

Reconhecimento das perícias médicas feitas pelos órgãos sindicais, visando à concessão dos benefícios acidentários, em caso de omissão do órgão previdenciário.

Obrigatoriedade de comunicação do acidente, moléstia profissional ou doença do trabalho à CIPA, para que tome medidas preventivas e conscientizadoras, visando evitá-los. Dessa comunicação, cópia deverá se remetida ao órgão sindical.

Determinação para que a aposentadoria por invalidez acidentária seja calculada pelo salário vigente à época do seu pagamento, sob pena de redução injusta.

Restauração do conceito de acidente do trabalho, moléstia profissional ou doença do trabalho, conforme o Decreto-Lei n. 7.036/44, com ampla proteção ao trabalhador e reconhecendo o direito ao pecúlio em caso de pequenos danos e seqüelas que resultem incapacidade inferior a $20 \%$.

\section{ASSISTÊNCIA MÉDICA DA PREVIDÊNCIA}

1.Por uma política nacional de saúde voltada para os interesses populares, onde seja priorizada a ampliação dos serviços públicos em to- 
dos os níveis. O papel dos hospitais privados deverá ser disciplinado, de forma a evitar prejuízos no atendimento à população e que sejam extintos os convênios com a medicina de grupo.

2.Pela criação de uma rede básica e pública de assistência médica obrigatória como porta única de entrada ao sistema de saúde e celebração imediata de convênios entre os poderes públicos federais, estaduais, municipais e entidades sem fins lucrativos, que assegurem a existência de um sistema médico, hospitalar e odontológico público em seus diversos níveis, que garantam a prestação desses serviços a toda a população.

3.Que seja assegurada a participação paritária dos trabalhadores através dos seus órgãos sindicais em todos os níveis no planejamento e sua execução.

4.Pela extinção dos convênios entre INAMPS de um lado e a indústria e grande comércio de outro, que dão margem à existência de empresas que intermediam a assistência médica hospitalar (medicina de grupo) objetivando interesses empresariais e o lucro com a assistência médica, convênios que atentam contra os interesses e a saúde de classe trabalhadora e seus dependentes.

5.Por uma política salarial no setor público especializado na área de saúde, para os seus profissionais, médicos ou não, que garanta condições de trabalho e salários condignos.

6.Pelo congelamento dos preços dos produtos farmacêuticos e que a Central de Medicamentos (Ceme) padronize, produza e distribua obrigatoriamente, no setor rural e urbano, os produtos farmacêuticos necessários ao atendimento médico hospitalar.

7.Pela unificação da assistência médico-hospitalar, odontológica, da Previdência Social rural e urbana com iguais direitos.

8.Eliminação imediata de cobranças de exames ou taxas de participação dos serviços médicos, hospitalares e odontológicos dos trabaIhadores rurais e pequenos produtores.

9.Que seja garantido pelo INAMPS o transporte dos trabalhadores rurais ou de seus dependentes até as localidades de atendimentos médicos e hospitalares. 
10.Que se procure eliminar a influência política de qualquer natureza nas alocações de equipamentos médicos, odontológicos para os sindicatos rurais e urbanos.

11.Que os sindicatos exerçam fiscalização sobre a assistência médica dos convênios, enquanto existentes, se houver renovação, que o mesmo tenha assistência dos órgãos sindicais, inclusive hospitais privados e dos serviços próprios da Previdência Social.

12.Que sejam assegurados aos trabalhadores os exames pré-demissionais e quando os mesmos apresentem alterações de sua saúde não tenham suas demissões homologadas pelo sindicato e quando homologadas por outros órgãos, o sindicato lute por sua anulação.

13.Que os exames pré-admissionais dos deficientes físicos sejam realizados, obrigatoriamente, pelo INAMPS, e que seja de sua obrigação colocá-los em uma função para quais estejam aptos e se inválidos Ihes sejam concedidos os benefícios da Previdência Social.

14. Que o DIESAT se fortaleça e transforme-se em uma entidade nacional nos moldes do DIEESE. Deve ser uma entidade de assessoria aos sindicatos, que por sua vez deverão organizar uma atuação permanente na exigência de ambientes de trabalho mais saudáveis.

15.Que toda e qualquer doença congênita ou adquirida deve ter assistência da Previdência Social, seja na habilitação ou na reabilitação por tempo indeterminado.

16.Que os órgãos sindicais intercedam junto às direções hospitalares no sentido de que as mesmas democratizem e procurem facilitar as visitas aos doentes hospitalizados sem prejuízo da ordem natural que os trabalhadores reconhecem necessária.

17. Que o movimento sindical exija que a assistência médica pericial do INPS cumpra sua verdadeira função sem qualquer interferência no ato médico do diagnóstico e concessão do benefício previdenciário.

18.Que a Previdência Social crie um serviço especializado de estudo e atendimento geriátrico ao paciente idoso.

19.Que os órgãos sindicais exijam como norma que os médicos dos convênios e do INAMPS atendam somente quatro pacientes por hora. 
20.Que os atestados médicos e odontológicos dos sindicatos, independentemente ou não da existência de convênios médicos sejam aceitos pelas empresas e por intermédio das federações de representação profissional, todos os sindicatos filiados incluam em seus contratos de trabalho, convenções ou acordos de trabalho, por ocasião das negociações coletivas com as entidades de representação patronal, cláusulas específicas nesse sentido.

21. Que o Instituto Nacional da Administração Médica da Previdência Social "- INAMPS, contrate profissionais de saúde para todas as modalidades de atendimento, para os trabalhadores previdenciários e seus dependentes.

22. Que os sindicatos e federações de representação profissional de todos os setores reivindiquem a instituição de uma carteira de saúde, na qual haja possibilidade de anotação de todos os casos de enfermidades a que estiver sujeito o trabalhador previdenciário, principalmente as doenças tidas como mais graves.

23. Que as conclusões obtidas neste conclave, juntamente com aquelas que serão extraídas no próximo congresso de caráter nacional, sejam de imediato encaminhadas e debatidas com os deputados federais e senadores da República, para que sejam apresentados projetos de lei com urgência. A mesma providência deverá ser adotada junto ao ministro da Previdência e Assistência Social, para que sejam o mais rápido possível colocadas em prática.

\section{Administração da Previdência Social}

1.Que sejam criados colegiados nos moldes daqueles existentes à época da vigência da Lei Orgânica da Previdência Social - LOPS, em todos os órgãos da Previdência e Assistência Social, em nível da administração central e nos estados membros, de modo a permitir a participação direta do trabalhador na gestão da Previdência Social, assegurando-lhe o poder de decisão.

Para a indicação dos representantes classistas a esses colegiados, será admitida a candidatura de trabalhadores aposentados, em igualdade de condições com os trabalhadores da ativa. 
2.Considerando que: a arrecadação oriunda do meio rural passou a integrar a receita do Sistema Geral da Previdência Social, dificultando que os trabalhadores rurais tenham um acompanhamento da aplicação integral dos recursos do ex-Funrural na concessão de benefícios da categoria; Considerando, ainda que o movimento sindical de trabalhadores rurais tem denunciado com freqüência a ação danosa de certos representantes locais do ex-Funrural.

Considerando, ainda, que estas representações têm geralmente seu titular escolhido nem por critérios políticos partidários, no mais das vezes não consultando os interesses dos trabalhadores rurais, nem mesmo da Previdência Social, gerando constantes atritos com os trabalhadores, negando benefícios de direito líquido e certo.

\section{Propõe:}

a)que a única maneira de corrigir tais abusos é permitir que os trabalhadores rurais sejam admitidos a colaborar na Administração da Previdência Social Rural, desde a representação local ou seu nível mais elevado;

b)que seja restituída a autonomia ao de Previdência Social Rural - ex-Funrural, estendendo-se aos trabalhadores rurais todos os benefícios e direitos dos trabalhadores urbanos, sempre observadas as peculiaridades existentes para o meio rural.

c)que em todas as assembléias, seminários e congressos, principalmente na próxima Conclat, estejam na "ordem do dia" a participação dos trabalhadores na gestão da Previdência Social.

d)que em todos os jornais sindicais se publiquem frases exigindo que o Brasil cumpra a Convenção 101 da Organização Internacional do Trabalho - OIT-- que trata da participação do trabalhador na administração de órgãos, cuja receita tenha parcela de contribuição do trabalhador.

e)que para fins de vetar os abusos generalizados do não-recolhimento das contribuições ao Instituto Nacional de Previdência Social - INPS, seja realizada ampla campanha, a fim de se conseguir lei obrigando as prefeituras municipais a só considerarem o alvará de localização e funcionamento, que é feito anualmente, aos interessados que apresentarem certidões negativas ao INPS. 
f)que seja denunciado o desvio enorme de verbas da Previdência Social para utilização em outras áreas, motivando desfalques de recursos e, portanto, mau atendimento dos segurados, além de problemas de ordem financeira, cobrando-se a recuperação dessas verbas, inclusive as destinadas às obras de hidrelétrica de Itaipu, que hoje, se atualizadas pelas ORTN, alcançam um trilhão de cruzeiros.

\section{Custeio}

Preliminarmente deve-se entender que não é possível separar do custeio o problema econômico nacional.

As mudanças na política econômica, justas ou não, são responsáveis pela recessão, agora inegável, e de refletir de maneira acentuada nas arrecadações da Previdência Social, fundamental fator para o seu custeio.

Assim é que a rotatividade da mão-de-obra, redução da jornada de trabalho em conseqüente redução de salários, desemprego, automatização nas empresas etc., a par da falta de sustentação própria de entidades como LBA e Funabem, contribuem negativamente para o custeio.

Paralelamente, a deficiente fiscalização das arrecadações, a falta de maior rigor na execução dos débitos para com a Previdência, a falta de uma rede própria para a completa assistência médica e hospitalar, propicia ponderável parcela da evasão de rendas, o que também ocorre nos acidentes pessoais com veículos automotores, quando as despesas ambulatoriais e hospitalares com acidentados são debitados à Previdência, não obstante cobertos por apólices de seguro obrigatório com empresas seguradoras de caráter particular.

\section{Faz-se necessário:}

a)que o seguro obrigatório dos veículos seja transferido das companhias seguradoras para a Previdência Social, tendo em vista que o resultado dos acidentes pessoais ocorridos no trânsito acarretam despesas em serviços e benefícios (assistência médica e aposentadoria por invalidez).

b)a ampliação da fiscalização previdenciária, usando para esse fim, inclusive o Dataprev;

c)a criação de um foro especial para julgar as empresas constituídas em mora previdenciária, bem como os crimes de apropriação indébita, 
quando não depositar as importâncias arrecadadas dos empregados, objetivando agilizar a celebridade processual nessa matéria;

d)esgotados os bens para o prosseguimento da execução judicial, sejam penhorados os bens patrimoniais dos proprietários individuais e ou diretores das empresas, reservando sempre bens para satisfazer os critérios trabalhistas, na forma preferencial privilegiada;

e)que sejam dotadas verbas no orçamento da União para o pagamento da dívida no prazo de dez anos, com correção monetária e juros de $12 \%$ ao ano, a partir de 1983;

f)que a Funabem e a LBA sejam regidas pelo MPAS através de dotação orçamentária da União, desvinculando destarte da Previdência Social.

2.Que sejam adotadas as seguintes modificações na sistemática de arrecadação:

a)volta da taxação dos lucros extraordinários das empresas;

b)taxação da contribuição previdenciária com base no lucro extraordinário das empresas;

c)fazer incidir alíquotas sobre aquisição de produtos suntuários, tais como: jóias, perfumes, veículos de luxo, importação, assim como fazer incidir sobre bebidas, com mais destaque de incidência na renda bruta da Loteria Federal, da Loteria Esportiva e a introdução da incidência dessa alíquota na Lotus, e elevação substancial da alíquota sobre o turismo externo.

d)a isenção de contribuição previdenciária nas construções de outros tipos de casas para evitar a evasão da arrecadação devida, determinou o acolhimento, por unanimidade, desta tese;

e)que seja implantado um setor específico junto ao DIEESE para proceder ao levantamento dos gastos públicos, destacando-se da arrecadação e dos gastos da Previdência Social, bem como o acompanhamento permanente, assim como recomendar também que o movimento sindical, em face dos elevados custos para tais levantamentos, prestigie maciçamente o DIEESE, mediante filiação e reforço financeiro necessário. 
3.Relativamente ao custeio da Previdência Social Rural, sejam mantidos os atuais sistemas de custeio, devendo-se buscar outras fontes como a taxação de produtos supérfluos consumidos pela população.

\section{Plano de ação}

1.Efetiva participação dos trabalhadores na administração da Previdência Social, em todos os níveis;

2.Ampla participação dos trabalhadores e profissionais da saúde na elaboração de uma política nacional de saúde que realmente atenda às necessidades da população;

3.Ampliação da rede de assistência médico-hospitalar e odontológica da Previdência Social;

4.Criação de uma rede básica e pública de assistência à saúde, gratuita e de bom nível, voltada para toda a população.

5.Extinção dos convênios médicos, concomitantemente com a criação de uma rede base e pública de previdência;

6.Congelamento dos preços dos produtos farmacêuticos básicos, com o fortalecimento da Ceme na produção e distribuição de medicamentos.

7.Unificação da assistência médico-hospitalar e odontológica da Previdência Social rural e urbana, com direitos iguais.

8.Adoção de medidas de segurança coletiva nos ambientes de trabalho, que preservem a saúde do trabalhador.

Além disso, os trabalhadores brasileiros manifestam-se vigorosamente nesta oportunidade contra:

a)a política de controle da natalidade imposta pelo governo sob o disfarce de planejamento familiar; e

b)o aumento do desconto do salário do trabalhador, de $8 \%$ para $10 \%$, para a Previdência Social, medida que se anuncia estar nas cogitações do governo para resolver os problemas que ele mesmo criou nessa área.

9.Que o Conclat discuta e encaminhe formas de luta para barrar o "Pacote Previdenciário". 


\section{POLÍTICA SALARIAL}

O fim da política de arrocho salarial implantada em 1964 tem sido uma das principais metas do movimento sindical, que nunca deixou de lutar contra a queda da renda da família trabalhadora e contra a falsa teoria de que os salários são os responsáveis pela inflação.

O salário mínimo, recebido por grande parte dos trabalhadores e usado como referência para fixar as remunerações em geral, não recuperou até hoje o poder aquisitivo de 1964 (que já era baixo) e deveria ser hoje de mais de $\operatorname{Cr} \$ 27.000,00$ (vinte e sete mil cruzeiros) para assegurar o sustento de uma pequena família, conforme mostra o DIEESE.

Os salários não foram afetados apenas pela política salarial. O fim da estabilidade no emprego e a criação do FGTS geraram uma alta rotatividade de mão-de-obra, pois os empregadores fazem demissões, principalmente, nas vésperas de reajustes oficiais, contratando depois novos trabalhadores com salários mais baixos.

Em novembro de 1979 foi adotada uma nova política salarial como forma de diminuir a pressão da classe trabalhadora sobre os patrões e o governo.

As vantagens principais dessa política são os reajustes semestrais com base num índice oficial de custo de vida, o INPC, e os reajustes maiores que o INPC para as faixas mais baixas, de um até três salários mínimos.

No entanto, permanecem muitos problemas:

- Não se mexeu nos lucros das empresas, em parte porque os reajustes maiores para as faixas mais baixas foram compensados pelos reajustes menores para as faixas mais altas;

- Os reajustes só de seis meses são insuficientes para acompanhar uma inflação que já passa dos $110 \%$ (cento e dez por cento) ao ano;

- Os servidores públicos foram excluídos dessa política;

- E o índice oficial é calculado sem a participação dos trabalhadores. 
Mas mesmo com esses defeitos a política salarial vem sendo atacada pelos tecnocratas e empresários que obedecem aos banqueiros internacionais. Assim, em dezembro de 1980 é estabelecido novo sistema de correção salarial através da Lei no 6.886, sendo reduzido de $80 \%$ (oitenta por cento) do INPC e o reajuste da faixa entre 15 a 20 salários mínimos, e eliminados os reajustes a partir dessa faixa. Finalmente, em maio último, o salário mínimo foi corrigido apenas em $100 \%$ (cem por cento) do INPC, com graves repercussões não só para os trabalhadores que recebem esse mínimo mas também para faixas superiores de reajustes, que terão portanto seus salários corrigidos por índices menores.

Assim, frente às limitações e deformações da política salarial e as perspectivas de revogação de alguns de seus aspectos mais positivos, cabe ao movimento sindical orientar sua luta com vistas aos seguintes objetivos:

1.Adoção de um salário mínimo real e unificado para todo o país que recupere o poder aquisitivo determinado pela Constituição.

2.Luta pelo reajuste de $100 \%$ (cento e dez por cento) do INPC para o salário mínimo.

3.Defesa do reajuste semestral; luta pelo reajuste trimestral no caminho da conquista dos reajustes salariais automáticos sempre que a elevação do custo de vida ultrapassar determinado percentual (escala móvel de salários).

4. Reajuste de $100 \%$ (cem por cento) do INPC para todas as faixas salariais acima de 3 (três) salários mínimos; de 1 a 3 salários, 110\% (cento e dez por cento) do INPC.

5.Extensão aos servidores públicos de todos os direitos das demais categorias.

6. Paridade dos aposentados com suas respectivas categorias.

7. Participação dos trabalhadores na elaboração do INPC através do DIEESE.

8. Efetiva liberdade de negociação direta do índice de produtividade e demais vantagens salariais. 
9. Unificação das datas-bases por categoria e em nível nacional.

10.Luta pela semana de no máximo 40 horas de trabalho com salário integral, preservadas as jornadas menores já conquistadas na luta de diversas categorias.

11.Unificação do piso salarial e do salário mínimo profissional, por categoria, em nível nacional.

12.Reajuste integral para qualquer trabalhador admitido pela empresa após a data-base, extensivo aos aposentados.

13. Luta pela estabilidade plena no emprego a partir da contratação.

14.Manutenção do FGTS em forma de um pecúlio para o trabalhador.

15.Instituição do seguro desemprego como instrumento complementar de defesa do trabalhador.

16.Pagamento de todas as horas-extras com $110 \%$ (cento e dez por cento) de acréscimo.

17. Luta pelo fim da política recessiva, entendendo-se que a questão do emprego está intimamente ligada à política salarial.

\section{POLÍTICA ECONÔMICA}

A crise em que o governo mergulhou o país com a implantação de uma política nitidamente recessiva, de acordo com os interesses dos banqueiros e grandes empresas nacionais e estrangeiras, está levando a classe trabalhadora a uma situação de insegurança e de extremos sacrifícios.

A pretexto de pagar a enorme dívida externa que os governos autoritários vêm contraindo ao longo dos anos, os atuais governantes decidiram que a ordem é entregar a Bacia de Campos, os minérios de Carajás, as terras de Mato Grosso, Minas e Goiás; internacionalizar o sistema financeiro, desnacionalizar o que resta da empresa privada nacional e privatizar empresas estatais mais rentáveis.

As principais medidas de política econômica que estão arrastando o país à recessão são a liberação dos juros, o controle do 
crédito, a fixação da correção monetária em níveis próximos ao da inflação, que já passa dos $110 \%$ por ano, os cortes nos gastos públicos. $\mathrm{E}$ as autoridades responsáveis por todo esse conjunto de desmandos econômicos jogam sobre as costas do trabalhador a quota maior de sacrifícios exigidos do povo brasileiro: o peso de uma dívida externa feita a nossa revelia, o desemprego, a queda real dos salários, o fim da política salarial.

Não temos, no país, um real planejamento econômico em todos os níveis. A concentração de renda é uma característica do modelo econômico brasileiro. E na hora de decidir por esse modelo não pediram nossa opinião. Mas diante de milhões de brasileiros que sofrem com o desemprego e o subemprego, com salários indignos e com condições de vida precárias, nós trabalhadores reunidos na $1^{\text {a }}$ Conclat, não ficaremos de braços cruzados. Nós sabemos, por nossa própria experiência, que só organizados e mobilizados poderemos conquistar nossos objetivos, garantir as conquistas que já realizamos, e influir em nosso próprio destino e no destino do país.

É por tudo isto que nós, trabalhadores, nesta $1^{\text {a }}$ Conclat não vemos outra alternativa senão a da mudança radical do conjunto da política econômica. Ao invés de a vida de 120 milhões de brasileiros estar subordinada aos interesses de uma minoria de banqueiros internacionais e nacionais e de grandes empresários, em sua maioria estrangeiros, nós, trabalhadores, exigimos uma política econômica que tenha entre seus objetivos a criação de empregos e a garantia nos empregos existentes, a melhoria dos salários e das condições de vida dos trabalhadores urbanos e rurais, e a justa distribuição da riqueza nacional.

É por tudo isto que, reunidos na $1^{\text {a }}$ Conclat, propomos os seguintes pontos básicos para a orientação da política econômica:

1. Estímulo à atividade econômica a partir de um programa de gasto de investimentos públicos gerador de emprego e não dependente de importações, que priorize áreas de carência social, tais como saúde pública, saneamento básico, transporte coletivo, habitação popular, educação, nutrição para carentes etc. $E$ que seja revista com urgência a ordem de prioridades das metas de desenvolvimento do governo. 
2.Implantação de uma política energética com vistas à redução de dependência do petróleo coerente com os interesses da classe trabalhadora, além da reativação da indústria ferroviária e do transporte ferroviário.

3.Estímulo à produção de gêneros alimentícios e de primeira necessidade, congelamento de seus preços e reformulação da atual estrutura de comercialização que implique o fim do intermediário, e que todos os sindicatos do campo e da cidade encampem esta bandeira e a da reforma agrária ampla, massiva e imediata.

4. Reforma tributária com incidência maior de impostos sobre ganhos de capital, heranças e valorização da terra e alívio da carga de impostos indiretos e sobre o salário. Isenção do ICM aos agricultores cuja área não ultrapasse 50 hectares, além da não-incidência tributária sobre a herança do pequeno proprietário, compreendido até 50 hectares. Fim da centralização dos recursos advindos de tributação pelo governo federal, causa do asfixiamento financeiro dos municípios brasileiros.

5.Revisão de todos os incentivos fiscais às empresas, controle da taxa de juros e fim da especulação financeira.

6.Aplicação dos fundos sociais (FGTS, PIS/Pasep, FADS), geridos pelos trabalhadores, eleitos por estes especialmente para isto, no financiamento de programas de investimentos sociais de interesse de classe a que se refere o item 1.

7.Congelamento dos aluguéis e prestações relativos às habitações populares.

- desvinculação das prestações dos agentes financeiros;

- que as construções do Sistema Habitacional sejam fiscalizadas pelos sindicatos dos arquitetos, engenheiros e trabalhadores da construção civil;

- pelo direito à infra-estrutura urbana (rede de água, esgoto, luz etc.).

-contra o despejo dos favelados e pelo direito de os moradores de favela continuarem nas áreas ocupadas. Qualquer transferência deve ser decidida em conjunto pela população favelada; 
- pela legalização e regularização dos loteamentos clandestinos sem qualquer ônus para o morador, e punição ao loteador;

- pela regularização das posses das unidades habitacionais atualmente ocupadas irregularmente;

- pela modificação da Lei do Inquilinato, de forma a atender melhor as necessidades do trabalhador, limitando as taxas de aumento de aluguéis;

- pela reformulação da lei do uso e ocupação do solo e dos códigos de obras dos municípios;

- pelo congelamento das tarifas de serviços públicos de infra-estrutura;

- pela criação do pacto de transporte, com direito à utilização de qualquer transporte urbano a um custo limitado a $5 \%$ do salário mínimo;

- criação de uma comissão de trabalhadores para dividir eqüitativamente as moradias disponíveis do sistema financeiro do $\mathrm{BNH}$;

- a produção da habitação é de responsabilidade exclusiva e fundamental do Estado e os recursos necessários devem ser obtidos sem qualquer tipo de ônus ao trabalhador. A habitação é um direito adquirido e inalienável do trabalhador como parte da justa remuneração de seu salário.

8.Fim da política recessiva do governo ditada pelo FMI, de diminuição dos gastos públicos, de redução creditícia, da liberação das taxas dos juros e de desemprego dos trabalhadores pela conquista da estabilidade no emprego.

9.Congelamento da dívida externa. A disponibilidade de recurso criada com o congelamento deverá ser usada como recurso de modo geral, para a solução da crise do país.

10.Monopólio estatal dos recursos minerais e energéticos sob o controle efetivo dos trabalhadores. Revogação da lei de permissão de recursos de capital estrangeiro na exploração de minérios e fim da concessão de isenção de impostos concedida a vários destes capitais hoje presentes em nosso país.

11. Nacionalização dos bancos estrangeiros e das empresas multinacionais e que eles obedeçam a um plano de aplicação de crédito de interesse nacional. 
12.Luta em defesa do meio ambiente.

13. Incentivo à pesquisa científica e tecnológica, através de projetos voltados para os interesses e necessidades dos trabalhadores e para o atendimento da política econômica definida na $1^{\text {a }}$ Conclat, e que se dê incentivo e prioridade ao desenvolvimento da nossa tecnologia com cientistas brasileiros dentro de nossas universidades e empresas estatais e seja desde já controlada a importação de tecnologia dos serviços técnicos a fim de limitar a remessa de lucros e a dependência externa.

14.Exigência de plenas liberdades democráticas, com o fim do governo militar para garantir a aplicação dos pontos acima definidos e a luta pela convocação de uma Assembléia Nacional Constituinte livre e soberana.

\section{REFORMA AGRÁRIA}

\section{Considerando:}

- que as condições de trabalho e a qualidade de vida dos trabaIhadores rurais estão a exigir, há várias décadas, a implantação da reforma agrária;

- que a implantação da reforma agrária não mais pode ser adiada, devendo ter seu início e o seu término definidos pelo poder público para que os trabalhadores sem terra possam integrar uma

sociedade humana e justa e ser uma força ativa produtiva, dotada da necessária participação política;

- que o conceito de reforma agrária não é a ocupação de espaços vazios ou terras públicas, através do processo de colonização, mas sim o conjunto de medidas que visem promover melhor distribuição da terra, mediante modificações no regime de sua posse, uso e propriedade, a fim de atender aos princípios de justiça social e ao aumento da produtividade;

- que a reforma agrária compreende a desapropriação das áreas que impedem e atrasam o processo de desenvolvimento econômico e social brasileiro; 
- que é indispensável a união e a participação dos trabalhadores, através de movimentos organizados para conquistar a sua efetiva realização;

- que a desvinculação do órgão executor da reforma agrária da Presidência da República e sua conseqüente transformação em mera autarquia, vinculada ao Ministério da Agricultura, implicou tamanha redução de poderes que, na prática, o INCRA perdeu sua condição de órgão executor da reforma agrária;

- que o GETAT, além de não ser reconhecido como órgão executor da reforma agrária só tem criado constrangimento e terror entre os trabalhadores rurais e agravado ainda mais os problemas sociais na sua área de atuação;

- que a justificativa oficial mais utilizada para a não-desapropriação dos latifúndios é a falta de recursos para a indenização e para a realização de obras de apoio nas áreas desapropriadas;

- que determinados programas e projetos oficiais que, muitas vezes, se auto-intitulam - "reforma agrária", têm marginalizado e desagregado os trabalhadores rurais que deveriam beneficiar;

- que a violência e as arbitrariedades contra os trabalhadores rurais têm aumentado nos últimos anos, provocando, inclusive, o assassinato de inúmeros trabalhadores, dirigentes sindicais e assessores, além do enquadramento de sindicalistas na Lei de Segurança Nacional.

\section{Proposições:}

1.- exigimos do governo a imediata decisão política de implantação da reforma agrária radical, ampla, massiva, imediata e com a participação dos trabalhadores rurais, visando promover a melhor distribuição da terra e modificações estruturais no regime de sua posse, uso e propriedade, a fim de atender aos princípios de justiça social e ao aumento da produtividade:

- reforma agrária ampla, quer dizer, que seja implantada em todo o território nacional;

- massiva, que dê acesso à terra a milhões de famílias de trabaIhadores rurais sem terra ou com pouca terra; 
- imediata, que seja estabelecido, com urgência um programa de reforma agrária, com metas anuais definidas e com prazo estabelecido para terminar;

- com a participação dos trabalhadores rurais, que os trabalhadores rurais participem de todas as fases de elaboração e execução do programa de reforma agrária.

2.- que se definam como formas ideais de assentamento capazes de promover a justiça social as propriedades de tipo familiar, cooperativo e coletivo;

3.- exigimos que o órgão executor de reforma agrária seja vinculado diretamente à Presidência da República e seja dotado de estrutura e recursos suficientes para a execução do programa;

4.- exigimos a extinção imediata do GETAT;

5.- exigimos a elaboração de uma lei criando o instituto da perda sumária da propriedade para aquelas propriedades não trabalhadas em regime de economia familiar que não explorem sua área agricultável;

6.- denunciamos à nação a existência de projetos oficiais, elaborados e executados em desacordo com o Estatuto da Terra, contrariando o interesse dos trabalhadores rurais, provocando sua marginalização e desagregação. Esses projetos são de responsabilidade do INCRA, Sudene, Sudam, BNDE, Codevasf, CHESF, DNOCS, Ministério da Agricultura, Secretaria de Agricultura e outros órgãos oficiais estaduais e federais;

7.- responsabilizamos o governo pela ocorrência de violências contra os trabalhadores rurais e suas lideranças, incluindo assassinatos, espancamentos, prisões e todo tipo de arbitrariedade, na medida em que permite a impunidade de seus autores e ainda enquadra os legítimos representantes dos trabalhadores e colaboradores na Lei de Segurança Nacional.

\section{Colonização Considerando:}

-que a colonização é colocada como pretexto para a não-realização da reforma agrária, nos moldes e forma em que a realidade brasileira a tem cobrado; 
- que imensas áreas públicas são entregues a empresas colonizadoras particulares;

- que as colonizadoras visam a lucro, encarecem os projetos, são presas fáceis do poder econômico/ político e não têm visão social do problema;

- que estas colonizadoras praticam toda sorte de irregularidades em favor do poder econômico e adotam diversas formas de pressão contra os trabalhadores rurais;

- que tais pressões visam marginalizar os trabalhadores nos projetos;

- que a colonização da Amazônia está sendo desenvolvida para atrair mão-de-obra barata para a região;

- que várias outras regiões se mantêm prejudicadas pelo latifúndio, que permanece intocável e causando tensões sociais.

\section{Proposições:}

1.- manifestamos nosso repúdio ao processo de colonização atualmente em curso;

2.- denunciamos a expulsão de colonos e posseiros e sua transformação em mão-de-obra barata e escrava, provocada pelos erros e desvios dessa colonização como alternativa oficial para não fazer a reforma agrária;

3.- exigimos que a colonização seja realizada somente por órgãos oficiais, com a participação do Movimento Sindical de Trabalhadores Rurais e não por colonizadoras particulares;

4.- exigimos a realização de uma colonização voltada para a criação massiva de unidades de produção de tamanho familiar em benefício dos trabalhadores rurais.

Problemas de terra: posse, grilagem, arrendamento e desapropriação por utilidade pública Considerando:

- que um volume escandaloso de terras públicas vem passando à propriedade privada de grandes grupos econômicos, principalmente estrangeiros; 
- que estes grupos, contando com o favorecimento oficial, representado pelos incentivos fiscais, retiram a oportunidade a milhões de famílias de trabalhadores rurais;

- que, sem outra alternativa, estes trabalhadores passam de posseiros e legítimos detentores de um pedaço de terra para a condição de mão-de-obra abundante e barata, quando não escrava;

- que os conflitos de terra têm a sua raiz na ação criminosa de grileiros que vêm expulsando os posseiros;

- que o poder público se omite em defesa dos posseiros:

- que o Poder Judiciário e o INCRA não vêm cumprindo sua missão de aplicar prontamente a lei ou solucionar os litígios de posseiros;

- que policiais tomam partido dos grileiros em prejuízo dos posseiros;

- que as desapropriações por utilidade pública têm sido causa de desagregação de comunidades rurais e de agravamento do êxodo rural;

- que obras construídas em nome da utilidade pública deslocam comunidades inteiras de trabalhadores rurais das áreas que habitam e cultivam, atingindo pequenos proprietários, arrendatários, parceiros, posseiros e assalariados rurais, a exemplo do que vem ocorrendo no Vale do São Francisco, com as barragens de Sobradinho e Itaparica: no Paraná, com a hidrelétrica de Itaipu; no Pará, com a hidrelétrica de Tucuruí;

- que é indispensável que se conheça e se divulgue a violência praticada contra os trabalhadores dessas regiões, os quais passam para uma condição humilhante de retirantes, sem teto e sem trabalho;

- que os trabalhadores dessas regiões não têm recebido do poder público nem mesmo as indenizações justas e prévias, estabelecidas pela Constituição Federal;

- que, ao contrário, têm tido suas posses e benfeitorias destruídas e, quando muito, recebem indenizações irrisórias e tardias.

\section{Proposições}

1 - condenamos e denunciamos a canalização massiva de incentivos fiscais em favor de "grandes projetos" manifestamente anti-sociais; 
2 - exigimos uma investigação ampla e vertical sobre o surgimento de imensos novos latifúndios a partir da concessão ou venda simbólica de terras públicas, com expulsão de posseiros e surgimento de áreas de tensão social e conflito;

3 - que seja vetada por lei a concessão ou alienação de terras públicas e grupos econômicos, e que as mesmas sejam distribuídas a trabalhadores rurais em ou com pouca terra;

4 - exigimos retorno ao domínio público dos latifúndios disfarçados em empresas, distribuindo-os a trabalhadores rurais;

5- reivindicamos que os processos discriminatórios sejam feitos por áreas menores, para evitar processos volumosos e lentos, dificultando o seu término;

6 - que sejam feitos com o rigor necessário, assegurando ao trabaIhador radicado na área o direito de nela permanecer;

7 - reivindicamos que as áreas arrecadadas pelo poder público nas ações discriminatórias, ao invés deserem leiloadas, sejam distribuídas a trabalhadores rurais sem terra;

8 - denunciamos o processo criminoso de grilagem, e cobramos medidas oficiais mais eficazes;

9- que o movimento sindical promova a denúncia ampla, perante a Nação, de todos os casos de grilagem; divulgando os nomes dos grileiros e de seus aliados;

10 - que as lideranças sindicais denunciem à opinião pública e às autoridades superiores os abusos de policiais, exigindo a imediata substituição dos mesmos;

11 - que as lideranças sindicais denunciem a falta de fiscalização do INCRA quanto aos contratos agrários;

12 - que as lideranças sindicais lutem pela desapropriação das terras em favor dos arrendatários e parceiros que as ocupam;

13 - que seja estabelecido o prazo mínimo de cinco anos para todos os contratos agrários; 
14 - reivindicamos a criação e implantação, em todo o território nacional, de uma Justiça Agrária para julgar todas as causas relativas ao uso, posse e propriedade da terra;

15 - que o direito agrário seja matéria obrigatória em todas as faculdades de direito, agronomia e administração pública;

16 - que o movimento sindical tome a iniciativa de denunciar todos os casos de corrupção no aparelhamento judiciário;

17 - exigimos que, nos casos de desapropriação por utilidade pública, todos os trabalhadores rurais atingidos sejam reassentados em terras que ofereçam as mesmas condições de fertilidade e situadas nos mesmos municípios ou na mesma região;

18 - que o movimento sindical tome posição quanto à necessidade de participação integrada das entidades sindicais de trabalhadores rurais nos casos de desapropriação por utilidades pública, em nível administrativo, para o fim de opinar e defender os interesses dos trabaIhadores na avaliação das indenizações, como também na elaboração e implantação dos projetos de reassentamento;

19 - que nos casos de desapropriação de áreas onde existirem arrendatários, parceiros e assemelhados, o movimento sindical exija que o pagamento de suas indenizações Ihes seja feito direta e coletivamente e não ao proprietário expropriado que, quase sempre, não lhes transfere as importâncias a eles destinadas.

\section{POLÍTICA AGRÍCOLA}

\section{Considerando:}

- que são pequenos agricultores aqueles que trabalham a terra em regime de economia familiar, detendo ou não a sua propriedade, sendo responsáveis por $50 \%$ de produção agrícola nacional;

- que a política agrícola do governo vem beneficiando quase que exclusivamente os grandes proprietários rurais, especialmente no que se refere ao uso de insumos e subsídios oficiais; 
- que a injusta política agrícola oficial se constitui em um dos fatores responsáveis pelo êxodo rural, pela diminuição do número de pequenas propriedades e pelo aumento dos latifúndios;

- que as reivindicações, recomendações e exigências, em relação à política agrícola, serão de efeito meramente paliativo, sem maiores conseqüências na vida dos trabalhadores rurais, se não se fizerem acompanhar pela implantação imediata e definitiva da reforma agrária, em todo o território nacional, capaz de assegurar os benefícios daquela política à grande maioria dos trabalhadores rurais e que a autonomia sindical é indispensável para que o movimento sindical possa fiscalizar a aplicação da política agrícola.

Após constatar que:

a)dadas as condições excepcionais do Brasil para o desenvolvimento de agricultura e que a balança de pagamentos está diretamente relacionada à produção agrícola;

b)sendo o Brasil um país que possui clima e solo para todos os tipos de produtos, tendo condições de ser auto-suficiente para atender às suas necessidades internas, através de estoques reguladores, e de, numa etapa posterior, exportar.

\section{Proposições:}

1 - que o poder público concentre todos os meios para incentivar as culturas de pequenos agricultores destinadas ao abastecimento interno, no estrito interesse nacional;

2 - que sejam suprimidos os estímulos e incentivos fiscais às grandes empresas agropecuárias voltadas para a produção de exportação e que os mesmos venham a ser concedidos aos pequenos agricultores, produtores de gêneros de alimentação, ou as suas cooperativas;

3 - que haja um melhor planejamento em nível nacional das áreas a serem plantadas, para que não ocorra falta de produtos essenciais; para tanto é preciso cuidar da diversificação das explorações, a fim de não haver importações de feijão, arroz, milho, cebola, carne e muitos outros produtos, pois a preocupação oficial está concentrada na exportação de um número bem reduzido de produtos; 
4 - criação de um programa especial de crédito, elevando-se os seus recursos de $10 \%$ para $50 \%$ para atender às reais necessidades dos autênticos pequenos agricultores, observando-se os seguintes critérios:

a)mínima burocracia;

b)juros mais baixos;

c)prazos mais dilatados;

d)garantia constituída somente pelo penhor da produção;

e)dilatação especial de prazos, sem acréscimos de juros ou correção monetária, e sem prejuízos de novos financiamentos, nos casos de frustração de safra e dificuldades de comercialização.

f)Que os financiamentos sejam estendidos aos pequenos agricultores não proprietários (posseiros, parceiros e arrendatários) sem necessidade de carta de anuência e sem aval, ou através de apresentação de contrato segundo o Estatuto da Terra;

g)Que os financiamentos sejam concedidos acompanhados de orientação técnica, e que esta respeite as necessidades e interesses dos pequenos produtores.

5 - que seja criado um serviço especial de assistência técnica, voltada para atender às necessidades dos pequenos agricultores, e que sejam respeitados seus costumes e a experiência por eles acumulada, exigindo-se do governo a celebração de convênios com as federações e sindicatos de trabalhadores rurais, para a livre contratação de técnicos agrícolas;

6 - que a introdução da mecanização não seja prejudicial ao aproveitamento da mão-de-obra, incentivando-se o uso da tração animal, a adubação orgânica e a policultura;

7 - nacionalização das empresas multinacionais que produzem insumos agrícolas (adubos, venenos etc.);

8- imediata reformulação do plano de emergência de combate aos efeitos da seca, no Nordeste, com a participação dos trabalhadores e da liderança sindical. 


\section{PROBLEMAS NACIONAIS}

A Conclat representa um acontecimento de maior importância para a classe trabalhadora brasileira e a sua realização um grande avanço no sentido de unidade de todos os trabalhadores, para, através de suas lutas, alcançarem suas justas reivindicações.

O país atravessa, no momento, grave crise econômica, política e social, cujas conseqüências têm sido, sistematicamente, jogadas nas costas dos trabalhadores brasileiros, que não são os responsáveis pela mesma. $\mathrm{O}$ atual regime, constituído pela aliança entre os grandes latifundiários, o grande capital financeiro nacional e internacional sustentado pelos militares é o responsável pela atual crise e pelos males que atualmente afligem a maioria da população brasileira. $O$ fim do atual regime militar é condição indispensável para se atingir e democracia no país. Objetivo esse, que interessa fundamentalmente a todos os trabalhadores e a maioria da nação.

Assim propomos lutar:

1.Por uma Assembléia Nacional Constituinte livre e soberana, cuja convocação seja precedida das seguintes condições:

a)liberdade de manifestação, reunião e organização para todos os setores da sociedade;

b)efetiva liberdade de expressão de todos os partidos e correntes políticas;

c)anistia ampla, geral e irrestrita, que extinga todas as punições políticas e sindicais;

d)livre e igual acesso aos meios de comunicação de massa, rádio, jornal e televisão, para todos os partidos e entidades sindicais de trabalhadores da cidade e do campo;

e)fim de toda a legislação de exceção e arbítrio e desmantelamento de todos os organismos de repressão; e

f)que o governo que a convoque seja o resultado da expressão de luta dos trabalhadores da cidade e do campo;

2.Que seja aprovado um Plano de Salvação Nacional que inclua: 
- congelamento da dívida externa;

- nacionalização dos bancos e monopólios estrangeiros;

- reforma agrária ampla, massiva e imediata;

- a revogação da Lei de Segurança Nacional, pela revogação das punições impostas aos líderes sindicais e aos trabalhadores nela incursos;

- a anistia ampla, total e irrestrita; pela liberdade de expressão, informação e reunião e de organização partidária;

- uma política de saúde e educação que atenda aos interesses dos trabalhadores. Pelo ensino público e gratuito em todos os níveis;

- uma política no setor de tecnologia e informática que atenda aos interesses dos trabalhadores e não sejam usadas para ajudar a oprimir o povo;

- Proclamamos que não cabe aos trabalhadores gerir a crise que não foi causado por nós, e tampouco fazer um pacto social com os responsáveis pela crise - as multinacionais e o regime militar.

Conclamamos também, a solidariedade internacional aos povos de El Salvador e Nicarágua na sua luta.

\section{PLANO DE LUTAS}

A Conclat, fruto das lutas dos trabalhadores nestes últimos anos, e concretização da necessidade da classe trabalhadora de se organizar e de se unificar para melhor enfrentar o patronato e o governo, ocorre num momento de suma importância. Período em que o país atravessa uma grave crise econômica gerada pelos patrões e seu governo, que lançam uma grande ofensiva contra os trabalhadores, traduzida em miséria e desemprego.

Contra isto os trabalhadores têm respondido com greve e mobilizações. Porém a atomização e oenfrentamento isolados nos debilita. Esta na hora de dar um passo à frente, através de um Plano de Lutas com reivindicações e calendários unitários que preparem a Greve Geral. 
Para isso o Conclat aprova:

\section{I - Reivindicações centrais}

a) Contra o desemprego - lutar por:

1 - Estabilidade no emprego desde o $1^{\circ}$ dia de trabalho;

2 - Salário-desemprego, pago pelo governo;

3- Redução da jornada de trabalho sem redução dos salários (jornada máxima de 40 horas semanais e escala móvel de horas de trabalho que assegure a manutenção e ampliação do quadro de funcionários);

4- Aplicação de um plano de obras públicas que atenda às necessidades da população e absorva a mão-de-obra desempregada.

b) Contra a carestia - luta por:

1- Congelamento dos preços dos gêneros de primeira necessidade;

2- Escala móvel de salários com reajustes salariais automáticas trimestrais, de acordo com o DIEESE;

3- Reforma agrária massiva, ampla e imediata com a participação direta dos trabalhadores, visando promover a melhor distribuição da terra e modificações estruturais no regime de sua posse, uso e propriedade. Garantia de preços justos para os produtos agrícolas;

4- Melhoria no atendimento médico e hospitalar sem qualquer taxa paga pelos trabalhadores além dos $8 \%$ (oito por cento), reajustes das aposentadorias e pensões de acordo com os reajustes da categoria do beneficiário e contra o pacote da Previdência Social;

5- Salário mínimo real, nacional e unificado que garanta a subsistência do trabalhador e de sua família.

c) Liberdade e autonomia sindical

1- Pelo fim das intervenções em todos os sindicatos de trabalhadores;

2- Pela absolvição dos dirigentes sindicais condenados pela Lei de Segurança Nacional. 


\section{II.Calendário}

1 - Dia $1^{\circ}$ de outubro: entrega das reivindicações ao presidente da República. Neste dia os trabalhadores se mobilizarão unificadamente num Dia Nacional de Luta, cujas formas serão determinadas localmente (por exemplo: atos públicos, marchas, assembléias e greve onde for possível) e dia 16 de novembro: prazo para que o governo responda às reivindicações. Concentração em Brasília neste dia com caravanas organizadas pelos estados, para receber a resposta do governo às reivindicações.

Neste dia os trabalhadores se reunirão em nível municipal, regional, estadual e nacional para avaliar as condições de deflagração.

\section{III.Formas e meios de mobilização}

1 - Que até a data da entrega das reivindicações, os sindicatos realizem assembléias para discutir com as bases o Plano de Luta e a necessidade da preparação de Greve Geral, caso as reivindicações não sejam atendidas. Que nessas assembléias se prepare o Dia Nacional de Luta em contato com outras categorias, definindo a melhor forma de luta em cada cidade.

2 - Que seja elaborado um cartaz unificado com as reivindicações centrais e o calendário aprovados. O encaminhamento do Plano de Lutas e as negociações ficarão sob a responsabilidade da Comissão Nacional Pró-CUT. 


\section{ENTIDADES PARTICIPANTES POR ESTADOS E NÚMERO DE DELEGADOS}

\begin{tabular}{|c|c|c|c|c|c|c|c|c|c|c|c|c|c|c|c|c|}
\hline \multirow{2}{*}{\begin{tabular}{|l} 
ESTADO \\
AM
\end{tabular}} & \multicolumn{2}{|c|}{$\begin{array}{c}\text { SINDICATOS } \\
\text { RURAIS } \\
\text { N }^{\circ} / \text { DELEGADOS }\end{array}$} & \multicolumn{2}{|c|}{$\begin{array}{c}\text { SINDICATOS } \\
\text { URBANOS } \\
\text { N}^{\circ} / \text { DELEGADOS }\end{array}$} & \multicolumn{2}{|c|}{$\begin{array}{c}\text { ASSOCIACCOES DE } \\
\text { FUNCIONARIOS } \\
\text { PÚBUICOS } \\
\text { No/DELEGADOS }\end{array}$} & \multicolumn{2}{|c|}{$\begin{array}{l}\text { ASSOCIACŌOES } \\
\text { NÜMERO DE } \\
\text { DELEGADOS }\end{array}$} & \multicolumn{2}{|c|}{$\begin{array}{c}\text { FEDERAÇŌES } \\
\text { RURAIS } \\
N^{\circ} \text { DE } \\
\text { DELEGADOS }\end{array}$} & \multicolumn{2}{|c|}{$\begin{array}{l}\text { FEDERACŌES } \\
\text { URBANAS } \\
N^{\circ} \text { DE } \\
\text { DELEGADOS }\end{array}$} & \multicolumn{2}{|c|}{$\begin{array}{l}\text { CONFEDERAÇOES } \\
\text { NÚMERO DE } \\
\text { DELEGADOS }\end{array}$} & \multicolumn{2}{|c|}{$\begin{array}{l}\text { TOTAL } \\
\text { ESTADOS } \\
\text { N DELEGADOS }^{\circ}\end{array}$} \\
\hline & - & - & 1 & 5 & - & - & - & - & - & - & - & - & - & - & 1 & 5 \\
\hline $\mathrm{AC}$ & - & - & - & - & - & - & 1 & 1 & - & - & - & - & - & - & 1 & 1 \\
\hline MA & 10 & 40 & 2 & 9 & - & - & 5 & 9 & - & - & - & - & - & - & 17 & 58 \\
\hline PA & 9 & 35 & 10 & 31 & - & - & 8 & 23 & - & - & - & - & - & - & 27 & 89 \\
\hline PI & 15 & 34 & 1 & 1 & - & - & 1 & 2 & 1 & 1 & - & - & - & - & 18 & 38 \\
\hline $\mathrm{CE}$ & 29 & 86 & 9 & 57 & - & - & 8 & 14 & 1 & 4 & - & - & - & - & 47 & 161 \\
\hline $\mathrm{RN}$ & 25 & 68 & 8 & 22 & - & - & 7 & 12 & 1 & 2 & - & - & - & - & 41 & \begin{tabular}{|l|}
104 \\
\end{tabular} \\
\hline PB & 15 & 39 & 9 & 30 & 1 & 6 & 5 & 18 & 1 & 1 & - & - & - & - & 31 & 94 \\
\hline $\mathrm{PE}$ & 37 & 79 & 9 & 59 & 1 & 1 & 8 & 44 & 1 & 3 & - & - & - & - & 56 & 186 \\
\hline $\mathrm{SE}$ & 1 & 7 & 2 & 7 & - & - & - & - & 1 & 1 & - & - & - & - & 4 & 15 \\
\hline $\mathrm{AL}$ & 9 & 22 & 7 & 37 & - & - & 5 & 25 & 1 & 1 & - & - & - & - & 22 & 85 \\
\hline BA & 23 & \begin{tabular}{|l|}
44 \\
\end{tabular} & 19 & \begin{tabular}{|l|}
137 \\
\end{tabular} & - & - & 12 & 71 & 1 & 4 & - & - & 1 & 5 & 56 & 261 \\
\hline ES & 2 & 15 & 10 & 98 & 2 & 6 & 6 & 28 & - & - & - & - & - & - & 20 & \begin{tabular}{|l|}
147 \\
\end{tabular} \\
\hline $\mathrm{MG}$ & 34 & 63 & 51 & \begin{tabular}{|l|}
317 \\
\end{tabular} & 5 & 36 & 10 & 39 & 1 & 3 & 2 & 15 & - & - & 88 & \begin{tabular}{|l|}
473 \\
\end{tabular} \\
\hline RJ & 23 & 51 & 48 & 444 & - & - & 19 & 85 & 1 & 2 & 5 & 28 & 1 & 1 & \begin{tabular}{|l|}
97 \\
\end{tabular} & 611 \\
\hline SP & 17 & 80 & 136 & 1210 & 14 & 77 & 37 & 182 & 1 & 7 & 8 & 41 & - & - & 213 & 1597 \\
\hline PR & 20 & 52 & 17 & 93 & 3 & 7 & 12 & 38 & 1 & 1 & 1 & 4 & - & - & 54 & 195 \\
\hline $\mathrm{SC}$ & 1 & 2 & 32 & 85 & 1 & 1 & 4 & 13 & - & - & 2 & 4 & - & - & 40 & 105 \\
\hline RS & 24 & 24 & 80 & 276 & 4 & 8 & 11 & 43 & 1 & 2 & 7 & 31 & - & - & 127 & 384 \\
\hline MS & 8 & 8 & 3 & 12 & - & - & 3 & 5 & 1 & 2 & - & - & - & - & 15 & 27 \\
\hline MT & 14 & 17 & 1 & 1 & - & - & 1 & 2 & 1 & 2 & - & - & - & - & 17 & 22 \\
\hline $\mathrm{GO}$ & 47 & 150 & 5 & 23 & - & - & 6 & 19 & 1 & 5 & - & - & - & - & 59 & \begin{tabular}{|l|}
197 \\
\end{tabular} \\
\hline DF & - & - & 9 & \begin{tabular}{|l|}
99 \\
\end{tabular} & 1 & 3 & 10 & 43 & - & - & 2 & 14 & 3 & 16 & 25 & 175 \\
\hline $\begin{array}{l}\text { TOTAL } \\
\text { GERAL }\end{array}$ & 363 & 916 & 469 & 3053 & 32 & 145 & 179 & 716 & 16 & 47 & 27 & 137 & 5 & 22 & 1091 & 5036 \\
\hline
\end{tabular}

\section{COMISSÃO NACIONAL PRÓ-CUT}

\section{ACRE}

MANOEL PACÍFICO COSTA

Associação dos Professores do Acre 


\section{ALAGOAS}

ARLINDO VITALINO DA SILVA

Federação dos Trabalhadores na Agricultura do Estado de Alagoas

\section{BAHIA}

\section{ALUISIO CARNEIRO}

Federação dos Trabalhadores de Agricultura do Estado da Bahia GONÇALO SANTOS DE MELO

Sindicato dos Petroleiros do Estado da Bahia

JOSÉ GOMES NOVAES

Trabalhador Rural de Vitória da Conquista

LAZARO BILAC DE SOUZA

Sindicato dos Trabalhadores nas Indústrias de Energia Elétrica, Hidro

e Termo-Elétricas no Estado de Bahia

\section{CEARÁ}

JOÃO MENDES

Sindicato dos Trabalhadores Rurais de Morada Nova.

RAIMUNDO GUERREIRO

Sindicato dos Metalúrgicos de Fortaleza

DISTRITO FEDERAL - DF

ARMANDO ROLEMBERG

Federação Nacional dos Jornalistas Profissionais

JOSÉ FRANCISCO DA SILVA

Confederação Nacional dos Trabalhadores na Agricultura. 


\section{ESPIRÍTO SANTO}

ANTONIO ÂNGELO MOSCHEN

Sindicato dos Trabalhadores Rurais de Colatina VITOR BUAIZ

Sindicato dos Médicos do Estado do Espírito Santo

\section{GOIÁS}

NÉLSON DE ASSIS TELES

Sindicato dos Trabalhadores Rurais de Bela Vista

MARANHÃO

JACÓ ALVES DE SOUZA

Sindicato dos Trabalhadores Rurais de Poção de Pedras

MATO GROSSO

EDVALDO JOSÉ DA SILVA

Federação dos Trabalhadores na Agricultura do Estado de Mato Grosso MATO GROSSO DO SUL

ANTÓNIO BEJAMIN F. COSTA

Associação Profissional dos Trabalhadores nas Indústrias Urbanas do Estado de Mato Grosso do Sul

PEDRO RAMALHO

Federação dos Trabalhadores na Agricultura do Estado de Mato Grosso do Sul

MINAS GERAIS

ANDRÉ MONTALVÃO DA SILVA

Federação dos Trabalhadores na Agricultura do Estado de Minas Gerais 
GUILHERME TELL F. GOMES

Sindicato dos Professores do Estado de Minas Gerais.

JOÃO PAULO PIRES VASCONCELOS

Sindicato dos Metalúrgicos de João Monlevade.

JOÃO SOARES SILVEIRA

Sindicato dos Metalúrgicos de Belo Horizonte e Contagem.

TILDEN JOSÉ SANTIAGO

Sindicato dos Jornalistas Profissionais do Estado de Minas Gerais

PARÁ

AVELINO GANZER

Sindicato dos Trabalhadores Rurais de Santarém

VENIZE NAZARÉ RODRIGUES

Associação Profissional dos Professores do Estado do Pará

PARAÍBA ÁLVARO DINIZ

Federação dos Trabalhadores na Agricultura do Estado de Paraíba

\section{PARANÁ}

AGOSTINHO BUKOWSKI

Federação dos Trabalhadores na Agricultura do Estado do Paraná ANTÔNIO P. DE SANTANA

Sindicato dos Trabalhadores da Construção Civil de Curitiba

PERNAMBUCO

EDVALDO GOMES DE SOUZA 
Sindicato dos Trabalhadores nas Indústrias Urbanas no Estado de Pernambuco.

JOSÉ ALVES DE SIQUEIRA

Sindicato dos Metalúrgicos de Recife.

JOSÉ RODRIGUES DA SILVA

Federação dos Trabalhadores na Agricultura do Estado de Pernambuco PIAUÍ

OSMAR ANTÕNIO DE ARAÚJO

Federação dos Trabalhadores na Agricultura do Estado do Piauí

\section{RIO DE JANEIRO}

\section{ERALDO LÍRIO DE AZEVEDO}

Federação dos Trabalhadores na Agricultura do Estado do Rio de Janeiro

IVAN MARTINS PINHEIRO

Sindicato dos Bancários do Rio de Janeiro

JOÃO CARLOS ARAÚJO SANTOS

Sindicato dos Petroquímicos de Duque de Caxias

JORGE RICARDO BITTAR

Sindicato dos Engenheiros do Estado do Rio de Janeiro

OSWALDO PIMENTEL

Sindicato dos Metalúrgicos do Rio de Janeiro

ROBERTO CHABO

Sindicato dos Médicos do Rio de Janeiro. 


\section{RIO GRANDE DO NORTE}

HORÁCIO PAIVA OLIVEIRA

Sindicato dos Bancários do Estado do Rio Grande do Norte

JOSÉ FRANCISCO DA SILVA

Federação dos Trabalhadores na Agricultura do Estado do Rio Grande do Norte

\section{RIO GRANDE DO SUL}

JOÃO PAULO B. MAROUES

Sindicato do Vestuário de Porto Alegre

LAURO HAGEMANN

Sindicato dos Jornalistas Profissionais de Porto Alegre

OLÍVIO DE OLIVEIRA DUTRA

Sindicato dos Bancários de Porto Alegre

ORGÊNICO ROTT

Federação dos Trabalhadores na Agricultura do Estado do Rio Grande do Sul

RICARDO BALDINO DE SOUZA

Sindicato dos Trabalhadores da Construção Civil de Porto Alegre WALTER JOSÉ IRBER

Sindicato dos Trabalhadores Rurais de Tenente Portela

\section{SANTA CATARINA}

FRANCISCO ALANO

Federação dos Empregados no Comércio do Estado de Santa Catarina 


\section{NORBERTO KARTMANN}

Federação dos Trabalhadores na Agricultura do Estado de Santa Catarina SÃO PAULO

ARNALDO GONÇALVES

Sindicato dos Metalúrgicos de Santos

CLARA LEVIN ANT

Sindicato dos Arquitetos de São Paulo

EDSON BARBEIRO CAMPOS

Sindicato dos Bancários de São Paulo

HUGO PEREZ

Federação dos Trabalhadores nas Indústrias Urbanas no Estado de São Paulo

JACÓ BITTAR

Sindicato dos Petroleiros de Paulínia

\section{LUIZ INÁCIO DA SILVA}

Sindicato dos Metalúrgicos de São Bernardo do Campo e Diadema RAIMUNDO ROSAS DE LIMA

Sindicato dos Padeiros de São Paulo

ROBERTO TOSHIO HORIGUTI

Federação dos Trabalhadores na Agricultura do Estado de São Paulo SERGIPE

MANOEL JÚLIO DE SANTANA

Federação dos Trabalhadores na Agricultura do Estado de Sergipe 


\section{COMISSÃO EXECUTIVA NACIONAL}

Em sua primeira reunião, realizada dia 11 de setembro, em Brasília, na sede Contag, a Comissão Nacional Pró-CUT elegeu sua Executiva composta de 23 membros efetivos e seis suplentes

\section{COMISSÃO EXECUTIVA}

Agustinho Bukowski André Montalvão

Antônio Angelo Moschen Armando Rollemberg

Arnaldo Gonçalves

Edvaldo Gomes de Souza Eraldo Lírio

Francisco Alano

Guilherme Tell

Hugo Perez

Ivan Martins Pinheiro

Jacó Bittar João Carlos Araújo

João Paulo Pires de Vasconcelos

Jorge Ricardo Bittar

José Francisco da Silva

Lázaro Bilac de Souza

Lauro Hagemann

Luiz Inácio da Silva

Olívio Dutra

Orgênio Rott

Raimundo Guerreiro

Roberto Toshio Horiguti

\section{SUPLENTES}

João Paulo B. Marques João Soares Silveira José Rodrigues da Silva Norberto Kartmann Oswaldo Pimentel Raimundo Rosas de Lima 